\title{
SUBJECTIVE FACTORS OF MODERNIZATION OF THE RUSSIAN EDUCATIONAL SYSTEM AND THEIR CONNECTION WITH THE PROBLEM OF EDUCATION SECURITY
}

\begin{abstract}
The article provides a socio-philosophical analysis of subjective interactions in education, which form a set of subjective factors of educational reforms from the standpoint of ensuring the security of the individual in education and the country's security. The author aims to identify the subjective factors of modernization of the Russian education system that determine both the risk of degradation of the education system and ways to strengthen and improve development. Modern social realities require that the system of Russian education, which has the reliance on their own cultural traditions, not losing touch with the best achievements of education in the Russian Empire, the Soviet education system, but also incorporates the best of the modern world experience of development of education and is based on the realities of education transformation in the global information society.
\end{abstract}

Keywords: modernization, education system, subjective factors, education security, national security.

Introduction

The study of the current state and prospects of development of the Russian education system is observed today in the works of many scientists, for example, S. V. Demchenko (2008), S. M. Mironov (2008), E. F. Moros, V. V. Goncharov (2020), N. V. Nalyvayko (2007), A. G. Savelev, S. K.Oznobishchev and S. V. Tselitsky (2008), O. N. Smolin (2011), V. M. Filippov (2013). However, despite a large number of studies, the complex set of subjective factors of modernization of the education system in Russia from the point of view of ensuring national security has not been identified. Subjective factors largely determine the processes of making and implementing specific decisions by educational institutions in the field of state educational policy, the functioning of real educational relations, both in the system of Ministerial management and in specific educational institutions and organizations. The decisions made should be based on the internal needs of society's development, on Russia's nati- onal interests, and ensure their protection, but taking into account the complex dynamics of external socio-political conditions. The prospects for the development of education in the country depend on the extent to which the priority of education declared by the subjects of educational policy is embodied in the actual optimal work of the country's pedagogical institutions and their labour collectives.

\section{Methodology}

The research methodology is based on sociophilosophical principles and methods of cognition that are widely used in the study of social processes and general scientific approaches related to the analysis of the modernization of the education system. This methodology allowed us to identify subjective factors of reforming the Russian education system from the point of view of educational security, which is determined by the specific impact of various social actors on it. 
Research Result

The conditions for the transition from the existing modern structures of education to a society where educational activity becomes much broader than the institutional system of education of the state in the traditional sense was the rejection of the old educational system in favour of a new educational society, when, according To R. Dave (1976), education is "intertwined with life" (p. 24). At the same time, educational institutions and other social institutions take educational functions into their competence. Educational activities are increasingly embracing society, and many are engaged in continuous self-education. The concepts of "educational environment", "learning environment", "educational space", "emerging society" are actively used. They all mean that education is provided for everyone, that everyone wants to learn and learns throughout their life. Management entities and decisionmakers play a significant role in education. In this activity and the educational process, several conflict situations and contradictions arise that generally determine the crisis processes in education. In particular, according to O. N. Smolin in Russia, unfortunately, in the higher education system, the authorities efforts are often aimed at replacing the problem of improving the quality of education with questions about reducing the number of students studying and reducing the number of universities. However, the desire to restrict citizens' access to full-fledged education can be considered an attack on their well-being and quality of life. It can cause an increase in social tension. Often formal indicators for monitoring the effectiveness of universities do not meet the stated goal of improving the quality of education, do not account for industry, economic and other characteristics of the universities. It has become a common phenomenon when a part of the inefficient universities are recognized leaders.

The best teaching departments, such as University departments, are "optimized", i.e. they are closed under any pretexts (mergers, cuts, re- forms, etc.). As a result, a significant part of experienced teachers loses their jobs, which are filled with new staff who are quite willing to be Tutors, i.e. simple transfer mechanisms of knowledge without their deep understanding and creative approach to education. The pyramid of higher education in Russia, built on the basis of bureaucratic criteria, stratifies universities, and the course to reduce their number deprives citizens of the right to affordable education. Among all the functions of state education management, only one - control has been hypertrophied. At the same time, the number of required accounting documents is growing on such a scale that it takes the form of paper genocide in education, teachers who constantly write accounting papers do not have time to teach. Against the background of the reduction of the teaching staff, the number of managers is constantly increasing, both in managing Ministerial, regional educational structures and in higher education institutions. These and other crisis phenomena and processes violate the security of domestic education, as well as create direct threats to the national security of our country (Smolin, 2011, p. 215).

In the educational space today, there are formal institutional subjects of education, which include subjects directly operating in the social Institute of education, communities of professional teachers and students, and managers in the field of education. Secondly, these are informal non-institutional subjects of education. First of all, people working in the media, libraries, religious institutions, theatres, museums, clubs, public, political and other organizations can influence the minds of students. Third, these are spontaneously active subjects of upbringing and education, for example, in the processes of communication with friends, participation in family life, neighbours, in informal associations, etc. The first of the above-mentioned subjective factors in relation to the education system can be designated as intra-system, acting constantly, directly, purposefully. On the other hand, the following two factors should be designated as non-systemic 
(in relation to the education system), which often act spontaneously, sometimes have an episodic character, but at the same time, they change the consciousness and behaviour of students in a certain way. Although formal institutional subjects of education, informal non-institutional subjects and spontaneous subjects of education are simultaneously active in the modern educational space, in fact, state educational policy directly manages only institutional subjects of education, omitting other subjective factors from its field of activity and thereby increasing risks and dangers in the field of education and public consciousness.

According to data provided by K. Knapper and A. Cropley (1985), in Norway in the 1970s, the formal education sector provided only $40 \%$ of the total amount of knowledge, and by 1990 this figure had decreased to $30 \%$ (p.201). Noninstitutional education entities develop various special programs (for example, in the field of health, family planning, agriculture, educational programs, youth clubs, etc.). In contrast, institutional education entities operate within the framework of the official unified educational system according to established norms and rules.

G. Koptazh (1991) writes that "institutional education has much in common with non-institutional education since both of these types of education are focused on providing the individual with a certain level of knowledge that cannot be obtained spontaneously. However, they differ significantly in their form and organization, subjects and content, and social groups of potential students. Moreover, institutional education implies mastering the entire program in a specific time frame, and non-institutional education is focused on small-time intervals since it adapts the amount of knowledge provided to specific needs of students and is highly flexible in introducing new approaches, methods and tools in education" (p. 57).

Of great importance for Russia is the idea of horizontal integration, which is based on the cooperation of schools and various educational in- stitutions with numerous informal areas of educational activity, including the local community, media, cultural and recreational institutions, family, neighbours, and so on (Khazova, 1997, p. 149).

In the $1977 \mathrm{~s}$, Hummel developed a model that asserts that the essence of continuing education is to ensure that the school system is supplemented by adult education and the development of professional skills with different types of parallel education. Hummel called education and upbringing in the family and preschool institutions the lowest level of the permanent education system, but the school is designed, in his opinion, not just to form a person but also to act as a cultural centre at the level of local society. Hummel considered extracurricular, non-institutional forms, in other words, parallel education, to be a significant element of the system of permanent education: cultural institutions (theatres, museums, exhibitions, cinemas, societies for the dissemination of knowledge, creative unions), peer groups, and the media. It is important to note that coordination within the integration process and all education centres as a single system reflects the effectiveness of continuous education. The main difficulty in implementing the presented model, from the point of view of its author, is caused by the complexity of the process of integrating noninstitutional forms into other forms of education. The social philosophy of education here testifies to the unity of the educational space, where the interaction of all subjects of the educational space should be organized. It is well known that non-institutional learning is primarily spontaneous, but it can be coordinated and planned. At the same time, according to H. Hummel (1977), "it is non-institutional forms that are most suitable for implementing the concept of permanent education since they are very flexible and better perceive changes in comparison with the traditional form of education in schools, which is quite conservative and difficult to reform" (p. 12).

In order to provide people with the necessary 
information about the possibilities of different forms of education at different levels, it is essential to establish organizations to help them choose a particular form of education according to specific educational needs. These organizations, according to J. Payne (1985), "are intended to become an important element of the system of permanent education, since according to the results of the research, which confirm simple observations, the main reason for the non-participation of the population in permanent education is precisely the lack of necessary information about the available methods and forms of education. Therefore, adult education institutions, the higher education system, local self-government bodies on education, trade unions, and youth organizations can perform Advisory functions" (pp. 3554).

The opening of consulting organizations is significant for Russia. In this regard, it is necessary to develop different forms of advertising about existing centres, courses, programs, and the formation of information services. The analysis of modern social processes clearly shows that education is no longer the prerogative of only formal institutions (educational institutions). New forms of education that were previously only part of various spheres of public life are acquiring an educational status. There is a gradual blurring of lines between different types of subjects of the education system and the programs they implement, and students, in turn, have the opportunity to choose any option they like or mix different forms of education (Carethe, 1977, p. 26)

Various subjects of the Russian education system use different means of the traditional knowledge system and new types of communication in their activities, such as computer social networks, information networks, television, integration scientific, educational and industrial areas, and the current educational potential of national cultures. In fact, it depends on them how the national educational space and the education system will develop. In this sense, the chosen means and methods of teaching and the goals of the pedagogical process are determined mainly by the subjective factors of modernization of the education system in Russia.

According to O. V. Dolzhenko, "the need for transition to continuous education is explained by the very complexity of the knowledge system, which, being widespread in society, needs a specific organization of its life activity as an active single integral organism, but all elements of this organism are to a certain extent Autonomous in terms of performing their specific functions and tasks" (Dolzhenko \& Shatunovsky, 1995, p. 58).

This integrity is provided by the communication space, which is given an important place in the media. Using modern information technologies, UNESCO plans to conduct a study on the feasibility of creating a worldwide satellite educational network. Of course, modern communication tools appear in the context of our research as important subjective factors in the modernization of the education system in Russia since they have a powerful impact on their audiences. Still, the nature of such impact raises many questions. N. A. Lurya (1994) rightly points out that "the infrastructure of new types of communications does not have subjects with clear regulations, which is a consequence of the very essence and nature of new communication systems and tools. In particular, television can have a serious educational and educational impact, but the means of controlling it are beyond the channels that provide this impact - the educational space and educational policy. Subjects with authority to manage communication tools may indirectly relate to the educational space or not intersect with it at all" (pp. 16-20).

In order to counter the unmanaged educational impact of modern communication systems in the global flow of information requires, above all, on the conceptual socio-philosophical level to develop measures of public control over the activities of that very problematic in terms of freedom of information (in particular, indicate numerous discussions about what kind of infor- 
mation and artistic products should provide the media with your audience). At the same time, in our opinion, it would be much more effective to think about possible methods and means of training individuals to analyze incoming information for its reliability and usefulness to develop their ability to perceive it selectively. The formation of these skills should become one of the most urgent tasks of the modern education system. In particular, it is necessary to develop and implement relevant subjects and teaching AIDS in teaching. The emergence of new forms of education and the spread of various educational services have become a response of society to the conscious needs of people. It is important to note that the criterion for assessing the degree of education of a society can be not only the branching of various state and public educational institutions or the degree of development of information channels in society but also the degree of satisfaction of individuals and social groups with the quality of education received, its relevance and effectiveness in solving the problems of these social groups and individuals. The prospects for the development of education largely depend on the extent to which the priority of education declared by the subjects of educational policy will be implemented in real life. Since policy begins with an awareness of the reasons for decisionmaking, it is necessary to explain and promote the importance of changes in education, to form public opinion in favour of prioritizing education as the most important condition for socio-economic progress in any other area.

In our opinion, ensuring national security through the development of the educational space depends mainly on improving the system of full secondary and higher education in Russia. Currently, students who finish grades 9 do not receive a full-fledged secondary education when entering a College in their speciality, 11 classes of education should be introduced, and only after their completion should graduates be accepted to colleges. More intensive development of e-universities is required. A modern electronic Uni- versity is a way to get a high-quality education for free and at any convenient time. In Russia, there is a practice of successful distance education. Some projects and universities have deployed training using remote technologies on their sites. Still, the closeness of these technologies, the repeated "invention of the Bicycle", did not allow them to expand widely and get the necessary support in government bodies. At present, it is necessary not to reduce the number of students, since this contradicts modernization, but rather to increase it. The development of each person's personality requires improving modern educational technologies and the national educational space as a whole. The creation of an integral cultural and educational space should be considered as a productive activity for the transition of education to the sphere of priority areas of development of society in the form of certain regional support and development programs. The emergence and formation of all types of the institutional, non-institutional and reasonable use of opportunities for occasional education. In our opinion, this is an absolute example of the development of Russian education. As a result, the problem of developing a Federal program for the development of education is extremely important. In this program, it was stated that the qualitative modernization of society is feasible through the qualitative modernization of education.

In our opinion, the degree of philosophical and theoretical developments on the issue of modern education in Russia, various programs for transformation and advanced technologies in the field of education can be the basis for creating a national Federal educational program. The existence of this program will be important for the implementation of productive strategic and tactical decisions in the development of the national educational system. Only if this socio-philosophical concept is used for the integrated application of economic, political, legal, social, and organizational measures it is possible to achieve real positive results in preventing destructiveness in modern Russia. As a necessary component, 
along with the state system for ensuring national security, the non-state system for ensuring national security also needs to be strengthened. In turn, it is necessary to take into account public associations as subjects of the non - state system of ensuring national security. As we can see, state and non-state governing bodies make up an integral system in ensuring national security.

Thus, in our opinion, civil society can be considered a social community formed in the course of self-organization, which is formed and operates within the framework of a sovereign state. It has a legally established right to control state institutions and influence their activities within the framework of providing protection of the legal rights and interests of an individual, a social group, and society as a whole. The presence of civil society as an association of independent individuals, creating the interacting formal and informal organizations and public institutions, represents one of the most, if not the defining provisions of the development of democracy and the rule of law. Article 30 of the Russian Constitution states: "Everyone has the right to unite... freedom of activity of public associations is guaranteed". Article 13 stipulates that: "Public associations are equal before the law". Nevertheless, it is necessary to legislate the competence of public associations in the field of national security since formal and informal associations have their own characteristics. Their activities should be regulated in all areas of public relations, which should be reflected in the law "on public associations" (Constitution of Russian Federation. Adopted by popular vote on 12.12.1993).

As a result of considering the specifics of the activities of public associations, it can be stated that they exist in the form of secular and religious groups and organizations. They can carry out their activities as formally fixed in the proper state authorities but also act without proper proof of their position. In fact, there are two types of public associations: formal and informal, which equally affect the changes taking place in society, including the area of national security. For this reason, in particular, V. M. Miroshnichenko (2002) rightly argues that in modern Russia, "there is a real need and inevitability of broad involvement of public associations in cooperation with state bodies in ensuring the national security of the Russian Federation" (p. 21). A similar practice is already available and tested by geopolitical rivals of Russia. At the same time, the interaction of the state and civil society refers to all spheres of social relations and main processes that in any way affect national security. As Eromasova A. A. (2007) notes, "public authorities in the United States of America rely and interact with an extensive infrastructure of civil society, based on a high homogeneity of ideological, political and value attitudes of the population" (p. 99). Using the existing ideological basis, the establishment of American global hegemony and the results of high material wellbeing of a part of the population, the state establishes the activities of civil society institutions along the way of interaction with specific subjects of national security (Lyubimov, 1993, p. 212).

In the United States of America, the state seeks to enlist the support of the majority of the population in the face of all kinds of public secular and religious organizations. At the same time, state bodies are implementing, at least declaratively, measures to ensure the interests of non state actors in ensuring national security. Consequently, citizens and public associations take part in the implementation of state security policy.

In our opinion, such an approach to ensuring national security is incorrect. It is necessary to focus special attention on the significant impact of national and religious factors on public relations and their role in the implementation of national security functions, covering the field of education. In particular, modern Russia is characterized by such a situation that at the level of global trends, characterized by a reduction in the value of ethnic identities in some regions, Russian citizens have increased attention to religion. As a result, the role of confessional identities has 
increased. This must be borne in mind when ensuring the security of the formation of society, because it is the people formed on a specific territory, with a certain socio-political and economic system, characterized by a unique mentality, that seems to be the most important, as A. S. Ovrazhkin (2014) writes, "the subject of life in a global society. Ethnicity, therefore, acts as the boundaries of the space of social existence" ( $p$. 76). Social existence manifests a direct effect on the development of the individual, its activities. At the same time, the individual, social group, class and society form and develop their social existence. The human environment is not the only factor that determines the life of the individual. At the same time, this is a factor, as well as the particular features of a person, the process of personality formation. The basis for this process is society, the material and technical basis, and social relations that exist at the time of the individual's birth. In this regard, it is most necessary to ensure the safety of education to maintain a type of social environment that, on the one hand, would be conducive to the development of the individual and does not depend on national and religious affiliation, and on the other, would provide a state for preserving the national identity of the individual, combining the cultural and religious features of a particular people.

\section{Conclusion}

Thus, in modern Russian education, from the standpoint of national security, we can distinguish a number of subjective factors determined by the impact of various social actors on the sphere of education. These are formal institutional subjects of education, informal non-institutional subjects, and spontaneous subjects of education. In general, formal institutional entities operate within the framework of a common strategy, standards and training programs and can ensure the overall security of the educational space. At the same time, the following two groups - non institutional and spontaneous subjects-can affect education in different directions, strengthening or, on the contrary, weakening the social institution of education. Therefore, it is necessary to monitor the activities of these social actors from the standpoint of national security and ensuring the security of the educational space.

\section{References}

Carethe, W. (1977). Na pyti k nepreryvnomu obrazovaniyu - novaya rol' vysshikh uchebnykh zavedenii (Toward lifelong education - a new role for higher education institutions, in Russian). P.UNESCO, 26(1), 16-24.

Dave, R. H. (1976). Foundation of lifelong education. Oxford: UNESCO Institute for Education and Pergamon Press.

Demchenko, S. V. (2008). Natsional'naya bezopasnost' $i$ obrazovatel'naya politika $v$ sovremenoi Rossii (National security and educational policy in modern Russia, in Russian). Moscow-Orel: Orags Publishing House.

Dolzhenko, O. V., \& Shatunovsky V. L. (1995). Sovremenye metody i tekhnologii obucheniya $\mathrm{v}$ tekhnicheskom vyze (Modern methods and technologies of training in a technical university, in Russian). Moscow: High school.

Eromasova, A. A. (2007). Mental'nost' russkogo cheloveka kak fenomen natsional'noi kul'tury (filosofsko-antropologicheskii analiz) (Mentality of the Russian people as a phenomenon of national culture (philosophical-anthropological analysis), in Russian). (Doctoral dissertation). Saint Petersburg.

Filippov, V. M. (2013). Modernizatsiya rossiiskogo obrazovaniya (Modernization of Russian education, in Russian). Pedagogy, 3, 3-11.

Hummel, Ch. (1977). Education today for the world of tomorrow. Paris: UNESCO. 
Khazova, L. V. (1997). Kontseptual'nye osnovy $i$ opyt modernizatsii obrazovaniya: gumanisticheskie i gumanitarnye aspekty (Conceptual foundations and experience of modernization of education: Humanistic and humanitarian aspects, in Russian). Krasnoyarsk: KSTU Publishing House.

Knapper, K., \& Cropley, A. (1985). Lifelong learning and higher education. London: Kogan Page Limited.

Konstitutsiya Rossiiskoi Federatsii (Constitution of Russian Federation, in Russian). Collected legislation of the Russian Federation. 03.03.2014. No. 9.

Koptazh, G. (1991). Nepreryvnoe obrazovanie: Osnovnye printsipy (Continuous education: Basic principles, in Russian). Alma Mater, 6, 57-58.

Lurya, N. A. (1994). Obrazovanie: poisky, nadezdy, sversheniya (Obrazovanie: Search, hope, fulfillment, in Russian). Obrazovanie v Sibiri (Education in Siberia, in Russian), 1, 16-20.

Lyubimov, L. L. (1993). Tsivilizatsionyi protsess $i$ sotsial'nye itogi razvitiya SSHA (The civilizational process and social results of the development of the USA, in Russian). Moscow: Foundation "For economic literacy".

Mironov, B. B. (2008). Obrazovanie kak osnovopolagayushchaya tsenost' $i$ opasnosti ynifikatsii (Education as a fundamental cultural value and the dangers of unification, in Russian). Vestnik, 2(43), 127 136.

Miroshnichenko, V. M. (2002). Nazionalnaya bezopasnost' Rossiskoi Federatsii (National security of the Russian Federation, in Russian). Moscow: Exam.

Moros, E., \& Goncharov, V. (2020). Modern dangers in the development of the Russian education system and ways to overcome them: Socio-philosophical analysis. Wisdom, 2(15), 114-128.

Nalyvayko, N. V. (2007). Problemy bezopasnosti sistemy otechestvenogo obrazovaniya (Problems of security of the national education system, in Russian). Philosophy of Education, 3(20), 21-26.

Ovrazhkin, A. S. (2014). Sotsial'naya filosofiya obrazovaniya (Social philosophy of education, in Russian). Moscow: Triada.

Payne, J. (1985). Education guidance services and the provision of adult education. International Journal of Lifelong Education, 4(1), 35-54.

Savelev, A. G., Oznobishchev, S. K., \& Tselitsky, S. V. (2008). Rossiya i mirovoi opyt kontseptual'nogo obosnovaniya natsional'naya bezopasnost' (Russia and the world experience of the conceptual justification of national security, in Russian). Moscow: IMEMO RAN

Smolin, O. N. (2011). Sotsial'no-filosofskie aspekty obrazovatel'noi politiki $v$ usloviyakh radikal'noi trasformatsii rossiiskogo obshchestva (Socio-philosophical aspects of educational policy in the conditions of radical transformation of Russian society, in Russian). Moscow: Nauka. 